\title{
Desain Interior Hotel Alila dengan Langgam Modern Luxury Nuansa Budaya Jawa
}

\author{
Timotius Disa dan R. Adi Wardoyo \\ Departemen Desain Interior, Fakultas Teknik Sipil dan Perencanaan, Institut Teknologi Sepuluh Nopember (ITS) \\ e-mail:wardoyoadi@prodes.its.ac.id
}

\begin{abstract}
Abstrak - Kota Surakarta merupakan salah satu kota pariwisata yang menjadi andalan Provinsi Jawa Tengah. Masyarakat perkotaan pada saat ini cenderung sering kali tenggelam dengan pekerjaan dan kesibukannya sehari-hari hotel Alila menjadi solusi kebutuhan wisata bagi para wisatawan baik wisatawan dalam negeri maupun luar negeri. Sehingga mereka dapat menghilangkan kejenuhannya dan menikmati masa liburannya tersebut. Metodologi yang digunakan oleh peneliti adalah kualitatif dan tipe studi deskriptif yang mana pengumpulan data dilakukan dengan observasi, interview, dan dokumentasi. Konsep yang digunakan adalah modern luxury dan nuansa budaya Jawa, hal ini dilakukan karena latar belakang kota Solo sebagai kota budaya dan konsep Alila yang mengangkat budaya lokal dan tuntutan zaman yang serba modern. Tugas akhir desain interior ini akan membahas mengenai konsep yang akan diaplikasikan pada hotel Alila. Pada hotel beberapa area sirkulasi dirasa sudah cukup baik, akan tetapi pada beberapa area dirasa kurang memiliki cukup furniture, sehingga terlihat sepi. Pada beberapa bagian penempatan meja dan kursi dirasa masih kurang maksimal. Konsep yang digunakan adalah modern luxury dengan nuansa budaya Solo, hal ini sangat cocok karena hotel Alila menekankan budaya lokal dalam desain hotelnya.
\end{abstract}

Kata Kunci-Hotel, Jawa, Modern, Luxury.

\section{PENDAHULUAN}

$\mathrm{P}$ ARIWISATA merupakan salah satu sumber devisa negara selain dari sektor migas yang sangat potensial dan mempunyai andil besar dalam membangun perekonomian yang saat ini sedang bertumbuh.

Kota Surakarta merupakan salah satu kota pariwisata yang menjadi andalan provinsi Jawa Tengah. Kota Surakarta yang sering juga disebut dengan kota Solo ini mengusung slogan "Solo The Spirit of Java", slogan ini bukan suatu yang berlebihan, karena kota ini mampu menjadi trend center bagi kota atau kabupaten lainnya terutama disekitar Kota Surakarta, dalam hal sosial, budaya, dan ekonomi. Kota Surakarta ini merupakan salah satu kota yang mempunyai potensi pariwisata yang sangat besar.

Kota Surakarta atau sering disebut Solo, merupakan kota yang sedang mengembangkan diri sebagai kota budaya dan pariwisata. Hal tersebut terbukti dengan banyaknya penghargaan yang diraih Kota Surakarta terkait bidang pariwisata. Pada bulan November 2009 Kota Surakarta meraih Indonesian MICE Award 2009, terkait dengan Meeting, Incentive, Converece, and Exhibition (MICE) di wilayahnya Sebelumnya Kota Surakarta juga mendapatkan penghargaan Indonesian Tourism Award (ITA) 2009 dalam kategori Indonesian Best 2 Destination dari Departemen Kebudayaan dan Pariwisata RI bekerja sama dengan majalah Swa
Sembada, Kota Solo juga dianugerahi sebagai kota dengan aspek tata kelola pariwisata terbaik oleh Kementerian Pariwisata RI tahun 2016.

Kawasan Solo sendiri mempertahankan unsur budaya yang kuat, hal ini dibuktikan dari Landmark kota yang berupa artefak yang menampilkan karakter perwayangan pandawa lima yang diletakkan tepat di tengah perempatan kota. Dan beberapa gapura yang berada di kawasan Solo Baru juga dihiasi dengan lukisan batik yang merupakan ciri khas kota Surakarta. Hal ini dapat dimanfaatkan unuk membuat konsep desain hotel yang unik dan berbeda di kawasan Solo untuk menarik minat wisatawan yang ingin menginap dan berlibur di hotel.

Masyarakat perkotaan pada saat ini cenderung sering kali tenggelam dengan pekerjaan dan kesibukannya sehari-hari yang menyita tenaga dan pikiran. Hal ini dapat menyebabkan kejenuhan dan kelelahan. Memahami apa yang dilakukan orang saat ini dan apa saja yang mereka cari dari berwisata maka tidak berlebihan jika dikatakan bahwa wisata telah menjadi salah satu kebutuhan pokok manusia zaman sekarang untuk memenuhi salah satu kebutuhannya, sehingga kegiatan ini dapat dijadikan sebagai landasan berfikir oleh desainer bahwa wisata harus dikemas sedemikian rupa sehingga menarik.

Hotel Alila menjadi solusi kebutuhan wisata bagi para wisatawan baik wisatawan dalam negeri maupun luar negeri. Sehingga mereka dapat menghilangkan kejenuhannya dan menikmati masa liburannya tersebut, karena mereka dapat menikmati berbagai fasilitas yang ada di hotel serta mengenal budaya yang ada di Indonesia. Hotel Alila dirancang dengan konsep modern luxury dan nuansa budaya Jawa, hal ini dilakukan karena latar belakang kota Solo sebagai kota budaya dan konsep Alila yang mengangkat budaya lokal dan tuntutan zaman yang serba modern.

\section{A. Rumusan Masalah}

1. Bagaimana menerapkan unsur kebudayaan Jawa Tengah (Solo) ke dalam interior hotel agar dapat menjadi sebuah media pengenalan budaya lokal?

2. Bagaimana menciptakan sirkulasi yang menunjang efektifitas dan nyaman bagi pengguna hotel?

3. Bagaimana mendesain hotel agar sesuai perkembangan zaman?

\section{B. Tujuan}

1. Merancang dan menerapkan unsur kebudayaan Jawa (Solo) ke dalam interior hotel sehingga dapat menarik pengunjung dan wisatawan 
2 Untuk menciptakan sirkulasi yang efektif nyaman bagi pengguna hotel.

\section{URAIAN PENELITIAN}

\section{A. Metode Pengumpulan Data}

Metode yang digunakan adalah dengan memecahkan masalah yang ada menggunakan beberapa cara antara lain:

a. Observasi, teknik pengumpulan data dengan turun langsung ke lapangan. Survey dilaksanakan di Hotel Alila Solo

b. Studi Literatur, merupakan data sekunder yang dapat diperoleh dari jurnal, laporan penelitian, internet, koran, dan buku peraturan. Data dan informasi yang didapat:

- Tinjauan tentang Hotel Alila

- Tinjauan tentang hotel secara umum dan tipe hotel

- Tinjauan tentang ergonomic.

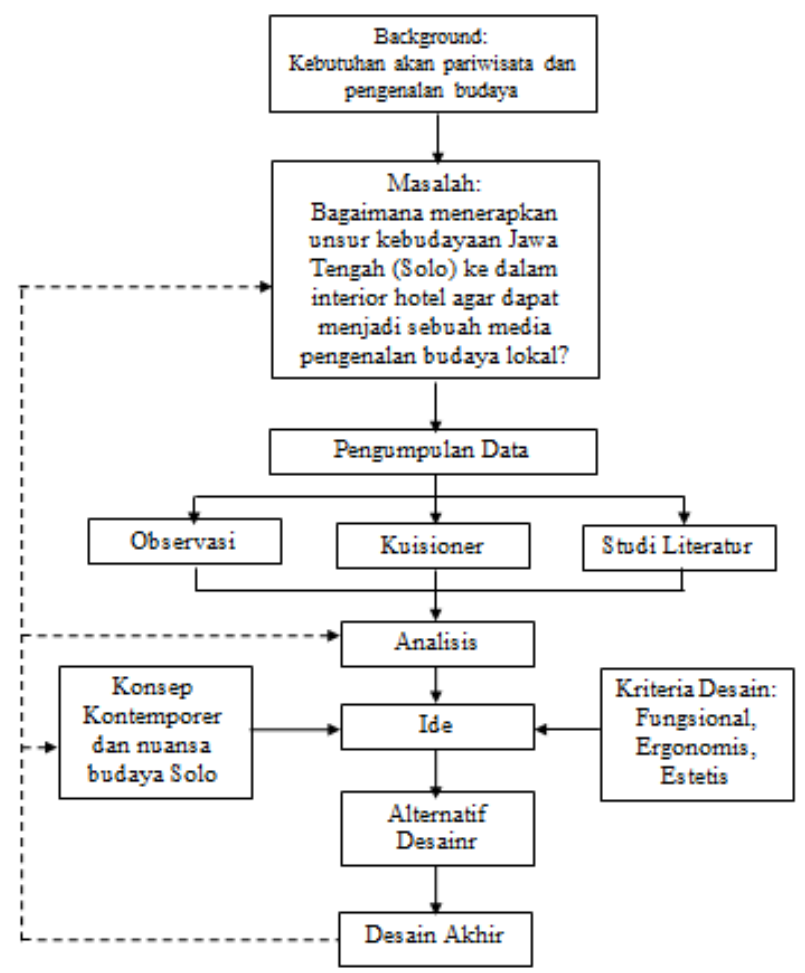

Gambar 1. Alur Proses Desain.

Sumber: Dok. Penulis.

\section{B. Metode Pengolahan Data}

Data-data yang telah terkumpul selanjutnya diolah dengan cara mengelompokan sesuai dengan perbagian. Setelah itu dilihat kembali atau disortir kira-kira data mana yang memang dibutuhkan dalam perancangan dan data mana yang tidak begitu dibutuhkan.

\section{Metode Analisa Data}

Metode yang digunakan dalam pengolahan data adalah dengan cara mengunakan metode induktif, yaitu dengan cara mengumpulkan semua data yang ada kemudian dianalisis berdasarkan literatur dan kemudian diambil kesimpulannya. Metode deduktif merupakan metode mengolah dan menganalisa data-data yang bersifat umum, kemudian menganalisa kembali data-data tersebut menjadi bersifat lebih khusus yang sesuai dengan judul perancangan. Data-data yang diperoleh melalui tahap pengumpulan yaitu data primer, dan sekunder kemudian digabungkan, dan dilakukan analisa untuk merencanakan konsep desain Hotel Alila Solo.

\section{KONSEP DESAIN}

\section{A. Konsep Makro}

Gaya yang digunakan pada perancangan ini adalah Modern luxury, gaya modernr dan luxury ini terlihat pada bentukan furniture, skema warna, dan penggunaan material yang akan diaplikasikan. Ditambah dengan nuansa budaya Jawa yang akan diterapkan di beberapa elemen estetis pada interior hotel. Nuansa yang dihadirkan dengan penggunaan motif batik sidomulyo yang akan dihadirkan pada beberapa elemen interior hotel.

\section{B. Konsep Mikro}

\section{1) Dinding}

Dinding kebanyakan menggunakan keramik dan granit berwarna krem, pemilihan granit digunakan karena memiliki warna dan corak yang khas, Menampilkan kesan yang elegan dan mewah, Memberikan kesan yang dinamis, dan mempunyai ukuran panjang dan lebar yang besar. Sebagian menggunakan beberapa panel gypsum. Pada bagian restoran dalam sebagian menggunakan kaca sebagai material dinding.
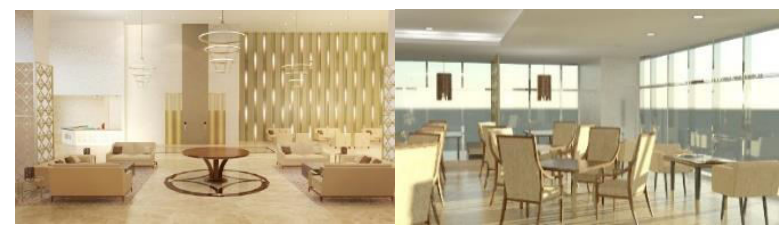

Gambar 2. Konsep Dinding

Sumber: Dok. Penulis

\section{2) Lantai}

Pada lantai hotel dominan menggunakan Granit berwarna cream karena granit memiliki daya tahan yang kuat dan memberikan kesan mewah. Serta pemberian motif geometris pada lantai agar senada dengan motif sidomulyo.

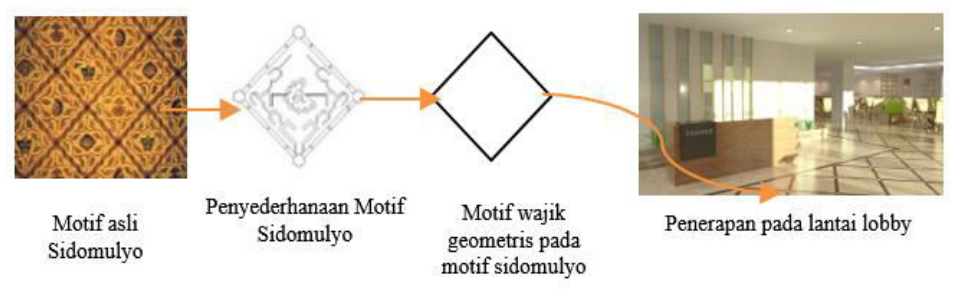

Gambar 3. Konsep Lantai

Sumber: Dok. Penulis

\section{3) Plafon}

Plafon secara keseluruhan menggunakan gypsum berwarna putih untuk menunjukkan kesan bersih. Serta permainan up ceiling atau drop ceiling untuk memberikan kesan yang dinamis. Material plafon lebih banyak terbuat dari gypsum karena mudah dibentuk, elegan dan mudah perawatannya. 

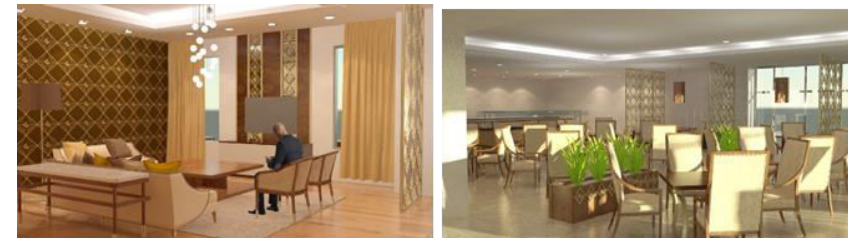

Gambar 4. Konsep Plafon

Sumber: Dok. Penulis

\section{4) Furniture}

Bentuk furniture yang digunakan memiliki bentuk yang sederhana dan tegas untuk menunjukkan kesan modern, serta terbuat dari bahan kayu untuk memberikan kesan natural dan hangat. Pada beberapa bagian kaki kursi diberikan besi cat emas untuk memperkuat unsur luxury. Pada cushion kursi makan diberikan kain motif sidomulyo dengan teknologi printing.

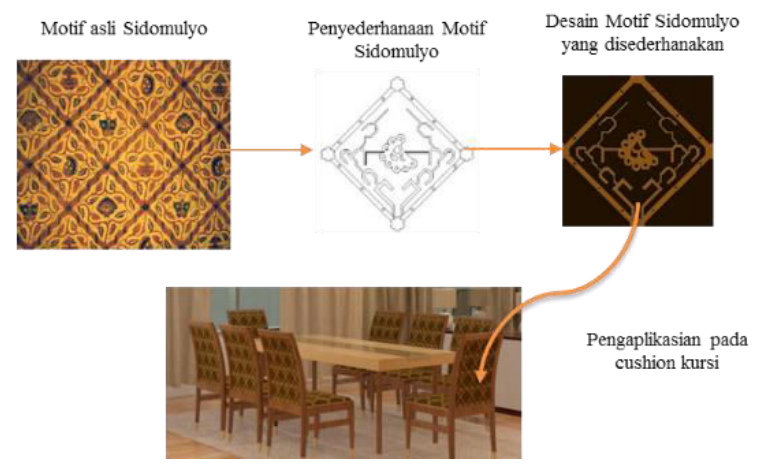

Gambar 5. Konsep Furniture

Sumber: Dok. Penulis

\section{5) Warna}

Warna banyak menggunakan gradasi coklat karena warna coklat merupakan warna khas dari batik Solo yang melambangkan kerendahan hati, Warna coklat digunakan karena merupakan warna yang memberikan kesan hangat seperti kayu. Serta juga menggunakan warna netral seperti hitam, putih, dan abu - abu serta warna emas yang emberikan kesan mewah.
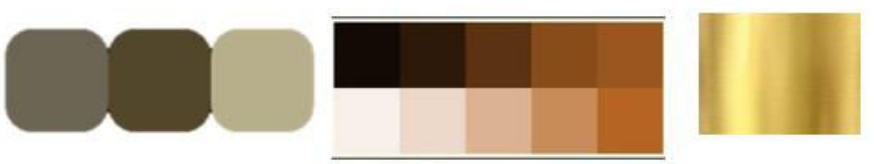

Gambar 6. Konsep Warna

\section{6) Pencahayaan}

Pencahayaan ruang yang dipakai adalah pencahayaan alami dan buatan. Untuk pencahayaan alami di siang hari terdapat jendela yang besar di lobby dengan pemandangan ke luar. Sedangkan pada malam hari menggunakan lampu downlight (daylight) pada restoran dan lobby.

\section{7) Penghawaan}

Pada hotel menggunakan jenis penghawaan sebagai berikut:

- Penghawaan alami

Sistem penghawaan alami digunakan dengan prinsip memasukkan udara bersih melalui lubang ventilasi sehingga terjadi sirkulasi udara masuk dan keluar.
- Penghawaan buatan

Penghawaan buatan digunakan untuk memberi kelembaban udara dan suhu ruang yang memenuhi syarat suatu ruang. Penghawaan buatan menggunakan exhauser fan dan air conditioner Central.

\section{DESAIN AKHIR}

\section{A. Ruang Terpilih 1 (Presidential Suite)}

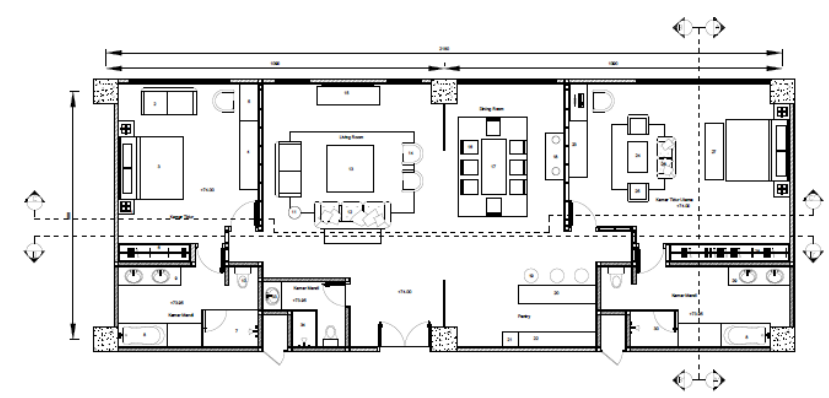

Gambar 7. Layout Ruang Terpilih 1

Sumber: Dok. Penulis

Pada Ruang Terpilih 1 merupakan presidential suite. Di dalamnya terdapat ruang tidur utama dan ruang tidur tamu, masing-masing dengan personal bathroom, dan dilengkapi living room, dining room dan pantry.

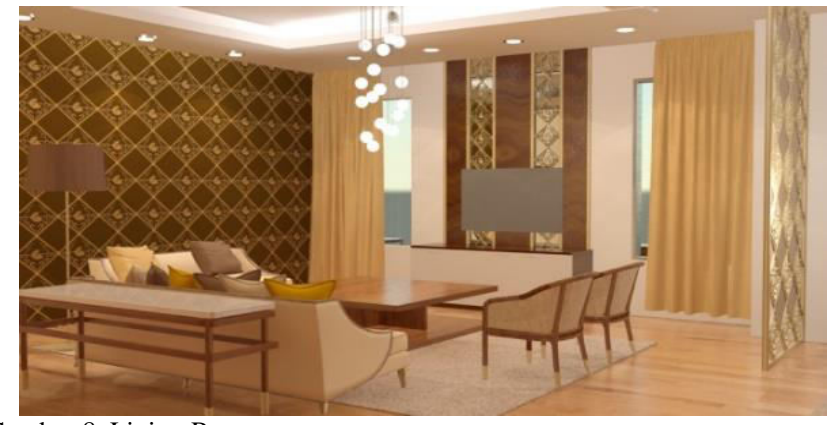

Gambar 8. Living Room

Sumber: Dok. Penulis

Pada area living room kesan modern dihadirkan melalui bentukan furnitur yang sederhana serta penggunaan warna gradasi coklat. Nuansa Budaya Jawa diaplikasikan pada cushion bantal sofa dan partisi dari cutting metal yang membagi area living room dan dining room.

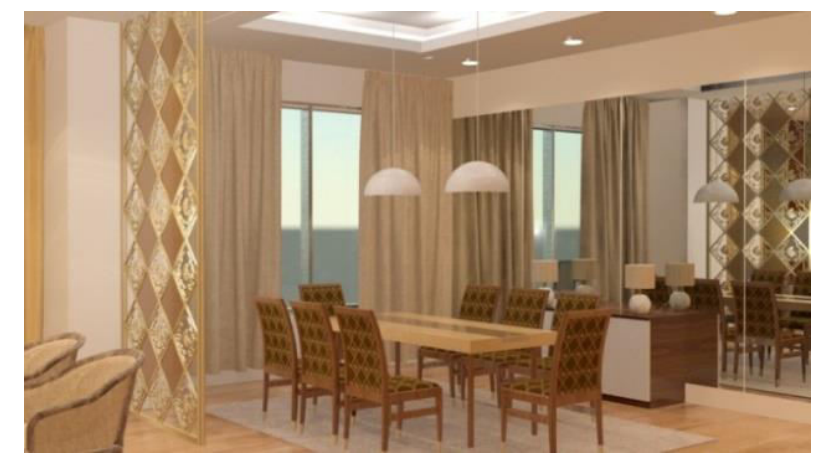

Gambar 9. Dining Room 
Sumber: Dok. Penulis

Pada area Dining room kesan modern dihadirkan melalui bentukan furnitur yang sederhana serta penggunaan warna gradasi coklat. Nuansa Budaya Jawa diaplikasikan pada cutting metal yang membagi area living room dan dining room.

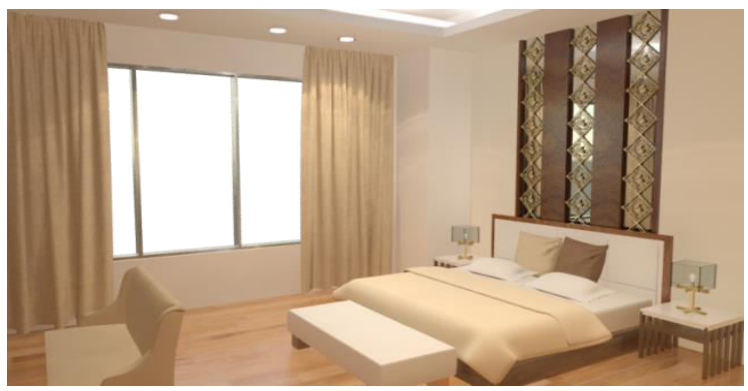

Gambar 10. Kamar Tidur Utama Sumber: Dok. Penulis

Pada kamar tidur kesan modern dihadirkan melalui bentukan furnitur yang sederhana serta penggunaan warna gradasi coklat. Nuansa Budaya Jawa diaplikasikan pada cutting metal yang terdapat pada panel yang ada dibelakang tempat tidur.

\section{B. Ruang Terpilih 2 (Restoran)}

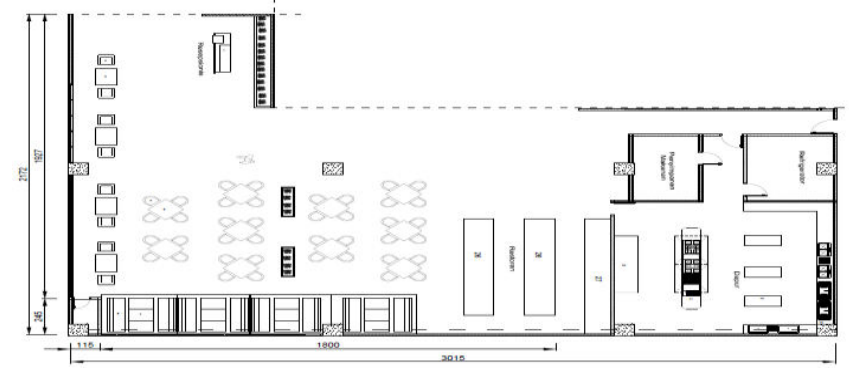

Gambar 11. Layout Ruang Terpilih 2

Sumber: Dok. Penulis

Pada area restoran terdapat meja respsionis untuk memesan meja atau makanan. Beberapa meja diatur secara diagonal untuk efisiensi tempat. Pada bagian depan juga terdapat buffet makanan.

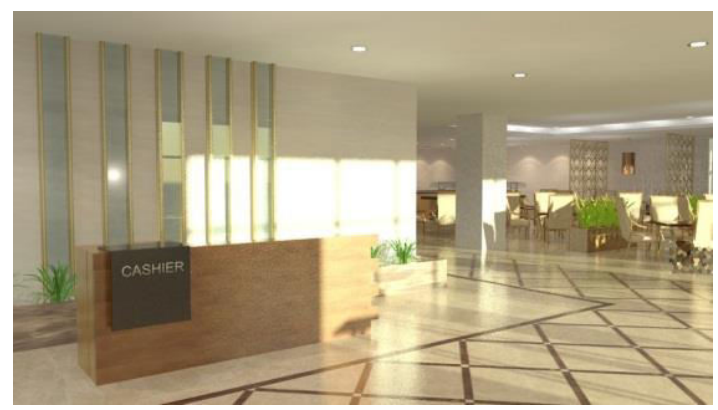

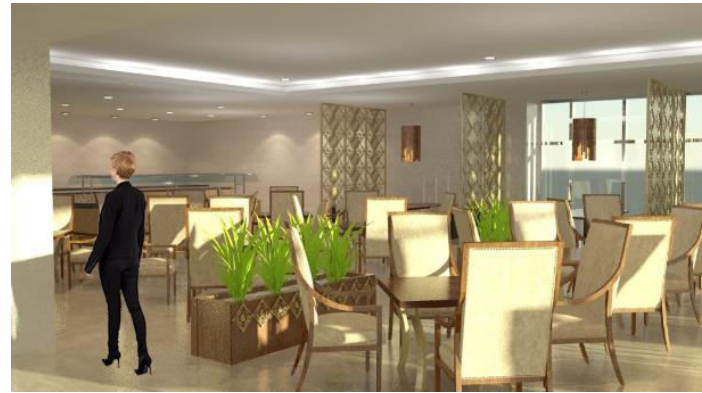

Gambar 12. Restoran

Sumber: Dok. Penulis

Kesan modern dilihat dari penggunaan bentuk furnitur yang sederhana dan penggunaan warna gradasi coklat dan netral. Meja resepsionis restoran terbuat dari material kayu untuk menambah kesan modern. Nuansa budaya Jawa dihadirkan dengan penggunaan partisi untuk membagi bangku pada area banquet.

\section{Ruang Terpilih 3(Lobby)}

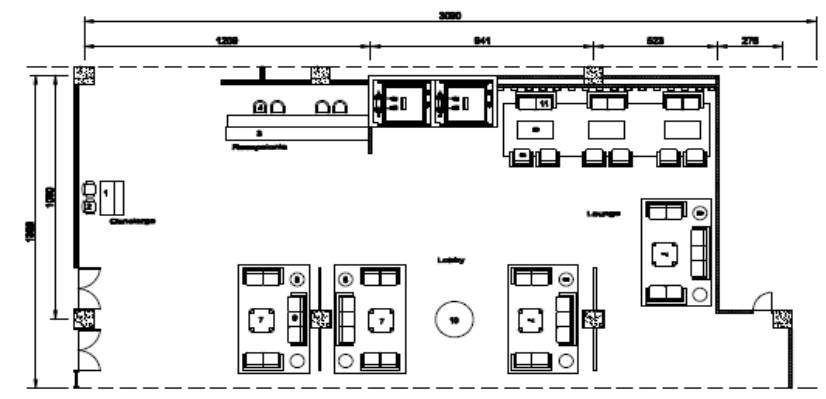

Gambar 13. Layout Ruang Terpilih 3 Sumber: Dok. Penulis

Pada Ruang Terpilih 3 merupakan area lobby. Pada area ini digunakan pengunjung untuk melakukan pemesanan kamar, serta untuk bersantai. Di area lobby terdapat bagian concierge, resepsionis, dan lounge yang merupakan area publik. Pada area lobby dan lounge terdapat tempat duduk untuk menunggu. Pada area lounge terdapat elemen estetis berupa lampu pada dinding.

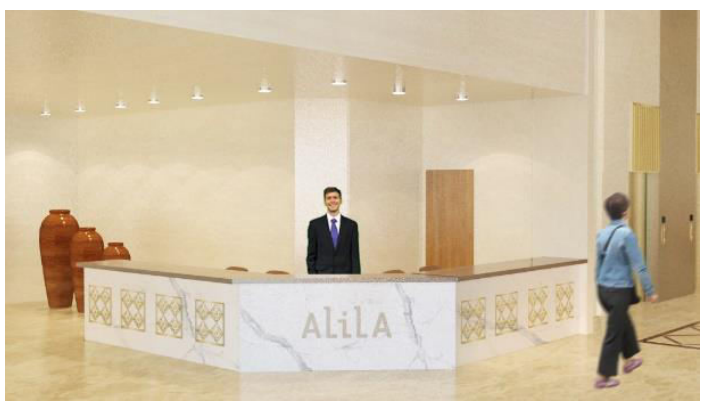




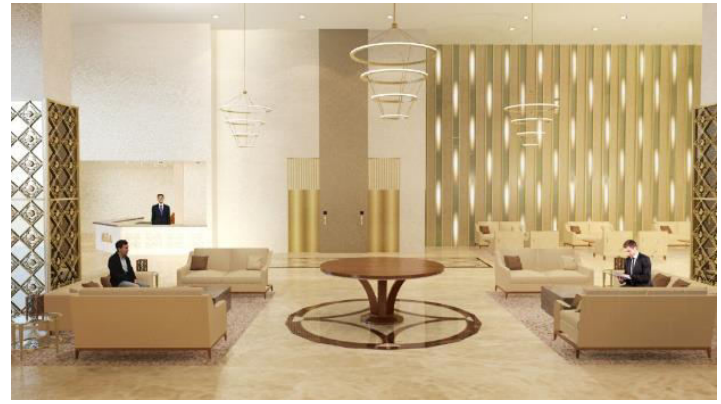

Gambar 14. Lobby.

Sumber: Dok. Penulis

Area lobby, area ini didesain dengan style modern bernuansa jawa. Pemilihan material glossy pada lantai dan elemen dinding menguatkan kesan modern serta kekinian. Ditambah dengan permainan lampu dinding yang sengaja di buat garis lurus untuk menguatkan kesan tersebut. Penggunaan material warna emas dan glossy juga memberikan kesan luxury. Nuansa Jawa dihadirkan dengan penggunaan partisi motif sidomulyo, dan permainan motif geometris yang senada dengan motif sidomulyo.

\section{KESIMPULAN}

Dalam desain interior hotel Alila dengan langgam modern luxury nuansa budaya Jawa, dapat diambil beberapa kesimpulan, yaitu:

1. Hotel Alila merupakan hotel butik yang dijadikan tempat menginap bagi wisatawan baik dalam negeri atau luar negeri untuk berlibur maupun bisnis. Aktifitas dan kebutuhan pengunjung diperhatikan dan dianalisa lebih lanjut sehingga dapat menghasilkan rancangan mengenai sirkulasi dan penzooningan area yang optimal yang dapat menunjang efektifitas dan kenyamanan pengguna hotel.

2. Pada hotel menggunakan konsep modern luxury untuk menampilkan hotel yang sesua dengan perkembangan zaman dan dapat diterima pada kalangan masyarakat, serta nuansa budaya Jawa untuk memperkenalkan budaya lokal kepada para wisatawan.

3. Unsur nuansa Jawa dihadirkan melalui aksen pada ruangan. Budaya yang dipakai adalah motif batik Solo yaitu motif batik Sidomulyo.Serta penggunaan warna gradasi coklat. Kesan modern dihadirkan melalui bentukan furniture yang sederhana dan tegas, Sedangkan kesan luxury dihadirkan dengan penggunaan material seperti cermin, besi dengan warna emas, serta finishing gloss(mengkilap).

\section{DAFTAR PUSTAKA}

[1] Kesolocom. 2016. 7 Motif Batik Solo Yang Paling Populer. Diakses dari: $\quad$ http://kesolo.com/7-motif-batik-solo-yang-paling-populer/. (Diakses 5 November 2016 pukul 19.00 wib.)

[2] Panero ,Julius, Martin Zelnik, 2003. Dimensi Manusia dan Ruang Interior. Jakarta : Erlangga.

[3] Soenarno, Adi. 2006. Front Office Management. Yogyakarta: CV. Andi Offset

[4] Suteja, Inez Natalia dan Mariana Wibowo. 2016. Re-Design Interior Boutique Hotel di Malang. JURNAL INTRA Vol. 4, No. 2, (2016) 224232. http://studentjournal.petra.ac.id/index.php/desaininterior/article/download/4632/4246. (Diakses 28 Oktober 2016 pukul 17.00 wib.)

[5] http://www.alilahotels.com/solo (Diakses 28 Oktober 2016 pukul 17.00 wib.)

[6] Utama, I Gusti Bagus Rai. 2015. Pengantar Industri Pariwisata. Penerbit Deepublish Yogyakarta CV. BUDI UTAMA. 